\title{
Slow tourism and railways: A proposal for the Italian-French Roia Valley
}

\section{Slow tourism e os caminhos-de-ferro: Uma proposta para a região franco-italiana do Vale do Roia}

\author{
Lorenzo Bagnoli \\ University of Milano-Bicocca, Department of Sociology and Social Research, Milan, Italy \\ lorenzo.bagnoli@unimib.it
}

\begin{abstract}
The slow tourism philosophy is usually directed, on the one hand, at mature tourist destinations with the aim of renewing them with up-to-date sustainable and responsible elements and, on the other hand, at promising destinations in order to help them enter today's extremely competitive tourism market. The Roia Valley, which since 1860 has been partly Italian and partly French, is the natural link between the maritime tourist region of the Riviera and the Côte d'Azur in the South, and the mountain resorts of Piedmont in the North, but it is not an important tourist destination per se. Nonetheless, since the 1920 s a very interesting railway has crossed the Roia Valley. This railway line, destroyed during the Second World War and entirely restored in 1979, has mainly been used for local transport or to connect the seaside with Piedmont, but it has not yet been exploited for local tourism. The aim of this research is to see to what extent a tourist exploitation of the railway line, through a slow tourism programme, could transform the promising Roia Valley into a new tourist destination closely connected to the mature Riviera and Piedmont regions.
\end{abstract}

Keywords: slow tourism; railway tourism; political tourism; international railways; Roia Valley.

\section{Resumo}

De um modo geral, a filosofia do slow tourism aplica-se, por um lado, aos destinos turísticos consolidados com o objetivo de renová-los com elementos sustentáveis e, por outro lado, aos destinos promissores, de modo a ajudá-los a entrar no atual, e extremamente competitivo, mercado turístico. O Vale do Roia é, desde 1860, uma região partilhada pela Itália e pela França, e é o elo natural entre a região turística de praia da Riviera e da Côte d'Azur, no sul, e as estâncias de montanha do Piedmont, no norte, não sendo, todavia, um destino turístico per se. Em 1920, construiu-se uma linha ferroviária atravessando o Vale do Roia que foi destruída durante a Segunda Guerra Mundial. Em 1979, a linha foi restaurada e tem sido utilizada essencialmente no transporte local e para fazer a ligação entre a beira-mar com Piedmont, mas ainda não foi explorada para o turismo local. O objetivo deste trabalho é analisar até que ponto a exploração turística da linha ferroviária, através de um programa de slow tourism, poderia transformar o promissor Vale do Roia num novo destino turístico intimamente ligado às regiões turísticas da Riviera e de Piedmont.

Palavras-chave: slow tourism; turismo ferroviário; turismo político; linhas ferroviárias internacionais; Vale do Roia.

Dos Algarves: A Multidisciplinary e-Journal, 27 - 2016. 


\section{Introductory remarks}

The 'slow movement' has been an engaging topic of research for many years now, so much that it seems to be not merely a passing trend, but a new philosophy of life altogether: a local, global and social approach currently characterizing a broad range of people, local communities and stakeholders (Calzati and de Salvo, 2012). Even though this is almost universally accepted, the actual meaning of 'slow' is not so widely shared. The term has in fact had the same misfortune as other similar ethical adjectives - such as 'sustainable', 'responsible', 'conscious' etc. - and its frequent use, and often abuse, has ended up confusing its meaning; so much so that it is now quite hard to give a univocal sense to it. If, on the one hand, this carelessness constitutes a flaw, on the other hand, 'slow' has now become a polysemic term, so that it can be used from different points of view, each of them involving an interesting perspective.

As far as tourism (or travelling) is concerned, this important human activity of our times has also been affected by the 'slow' dimension, and in this case there have also been different ways of considering the concept. Lumsdon and McGrath (2011) have summarized them into four features: slowness and value of time; locality and activities at the destination; mode of transport and travel experience; environmental consciousness. These will be discussed further at a later stage, but what is important to highlight for the moment is that the term 'slow' has been used regarding the quality sometimes of the experience, sometimes of the destination, sometimes of the journey and sometimes of the geographical impact. This confirms the vast polysemic character of the term when applied to the context of tourism research.

As the concept of quality has been introduced, it can now be explored further in relation to tourism. It is an irrefutable fact that nowadays the protection of resources and the valorisation of tourism cannot be achieved without a very high level of quality for the tourist, the local community and the environment (Shaw and Williams, 1994). In fact, up until some decades ago, tourism was mainly focused on providing travellers with the six Ss (sun, sea, sand, sex, spirit, and sport). This was because the tourist, unlike the local community, gave little importance to sustainability. Today this pattern has changed a great deal: more often than not, the tourism industry offers travellers not only the famous three Ls (landscape, leisure, and learning) instead of the six Ss, but also the $4^{\text {th }} \mathrm{L}$ 
(limit) to make sure they are satisfied with their experience (Franch, Sambri, Martini, Pegan and Rizzi, 2008). The 'new tourists' (Florida, 2002) are aware of the environmental, social, and economic impact of their activities and of their own responsibilities; they therefore accept, or might even look for, a 'limited' tourism experience. A journey inspired by the slow way philosophy, therefore, seems to meet this new desire of tourists, where quality is explicitly linked with limit (Georgica, 2015).

The case study of the Roia Valley, which will be considered in this paper, adds two more important and original aspects to the topic of slow tourism: the first is the issue of borders and borderlands, and the second is the fact that the entire valley is served by a railway line.

\section{Context}

The Roia Valley has been divided between Italy and France since 1860 (House, 1959), although in different ways. In 1860, with the cession of the County of Nice to France, the central part of the valley of $290 \mathrm{~km} 2$ in size (with Breglio/Breil, Saorgio/Saorge and Fontano/Fontan municipalities) was given to France, while the northern (with Briga and Tenda) and the southern parts (with Ventimiglia, Airole and Olivetta San Michele) remained in Italy. When Italy lost the Second World War, it had to give all the northern part of the valley to France (and the municipalities were renamed La Brigue and Tende), as well as the little hamlets of Libri and Piena (Libre and Piène), in the South; this means that the valley is now divided into two parts: the higher part in France, and the lowest one in Italy (Bagnoli, 2006; 2013). 


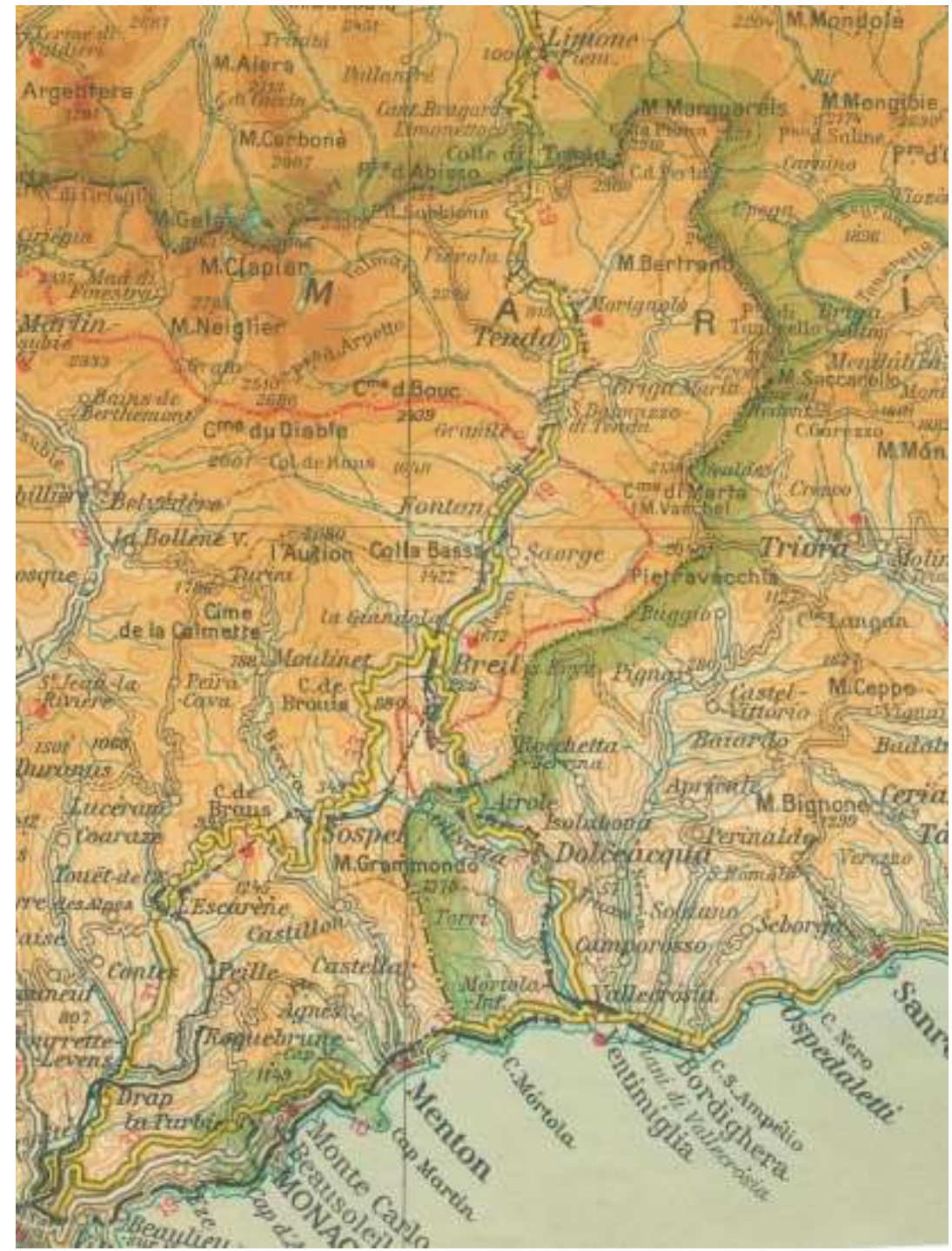

Source: Italian Touring Club archive.

Even though the valley is a natural link between the maritime tourist region of the Riviera and the Côte d'Azur, and the mountain resorts of the province of Cuneo (Piedmont), it is not an important tourist destination per se, especially when its partition into two states is taken into consideration (Lucarno, 1992). Nonetheless, since the 1920s, a very interesting railway has crossed the Roia Valley: a railway that was destroyed during the Second World War, and then entirely restored in 1979 (Schiavazzi, 1979). This historical railway constitutes a very important element of social identity for the entire valley. Until now this railway line has mainly been used for local transport, or to connect the seaside with Piedmont, but it has yet to be exploited for local tourism (Blancheton and Marchi, 2011). Therefore, the purpose of this research is to verify to 
what extent a tourism exploitation of the railway line, through a slow tourism programme, could transform the promising Roia Valley into a new tourist destination, closely connected to the mature Western Ligurian Riviera and the Piedmont Alps. To this aim, this paper has been set up in two parts, which are described in the following section.

\section{Methodology}

The first part of the study consists of a geographic overview of the region under consideration, with particular attention on the practicality of the railway, to ascertain if it is possible, according to the researcher, to introduce the new slow tourist praxis in the region. In terms of methodology, the traditional procedure of regional geography (Ruocco, 1993) has been used, considering in succession: the natural environment, the settled population and the economic activities of the region, not only at the time of the research, but also with a broader historic viewpoint.

The research tools used include the recognition of the state of art and field research. For the first part the main focus was on the literature, with particular attention on the geographic and historic ones, and on statistics supplied by the national public administrations (Institut National de la Statistique et des Études Économiques [INSEE] for France and Istituto Nazionale di Statistica [ISTAT] for Italy). For the field research, the study is based on more than a decade of practice in the region, in depth-analysis and updated during the last months of the research (May-July 2014), and informal interviews with local privileged witnesses and stakeholders (Loda, 2010). From this analysis, as will be shown, it emerged that the region seems adequate to meet slow tourism practitioners' tastes in several aspects.

During the second part of the research, the method of participative observation was used to verify the interest of potential slow tourists. A group of around fifty visitors, the majority of whom had never visited the region, was accompanied in loco for a day visit (September $\left.27^{\text {th }}, 2014\right)^{1}$ with the precise aim of determining from their behaviour and

\footnotetext{
${ }^{1}$ The fieldwork was carried out during the $57^{\text {th }}$ National Congress of the Italian Association of Geography Teachers, held in Sanremo from September $25^{\text {th }}$ to October $1^{\text {st }} 2014$, in which about 200 colleagues took
} 
their observations if the opportunity to launch slow tourism in the valley could be successful or not.

The main research method used was a focused ethnography method (Knoblauch, $2005)$ - i.e. a qualitative investigation over a short-term visit. While the short-term visit and the qualitative approach are common practices with the ethnographic method, this research had two peculiarities. The first consists in the fact no questionnaires were distributed, but the outputs were carefully observed and recorded by the researcher. This was done so as to be sure that the opinions were independent and sincere. However, at least on a couple of occasions, discussions with restricted groups of participants were oriented more or less towards the argument of slow tourism. The second peculiarity is that the group was composed mainly of geography teachers, from various Italian regions (plus one from France), from all kinds of school - from primary to university - and of all ages, even though the majority were aged 55-65 years old. Therefore, although the sample was not representative, the opinions obtained are particularly suited because the researcher believes that geography teachers - especially experienced ones - can give adequate advice about the research topic because of their training for accuracy and the depth of their territorial knowledge.

\section{The region}

The Roia River runs through the valley of the same name for $59 \mathrm{~km}$, flowing from the Tende Pass $(1,871 \mathrm{~m})$ in the Ligurian Alps to the city of Ventimiglia, on the Mediterranean Sea. The river basin is $662 \mathrm{~km}^{2}$ in size, and today 90\% of it is in France, with the remaining part in Italy. From a physical-geographical point of view, the rocks get younger and younger as you move from the source of the river towards its mouth. The valley is deeply carved, sometimes with steep canyons, where it is possible to admire tight meanders and deep giants' kettles, while other parts are more spacious and flat. ${ }^{2}$ Fundamentally, even though the valley is quite short, there are two climatic

part. In fact, the entire day of the $27^{\text {th }}$ of September was dedicated to travelling lessons, and I led 49 participants in the field on an excursion to the Roia Valley.

2 The glacial period left some interesting phenomena such as moraines, cirques glaciers, and roches moutonnées, mainly in the Vallée des Merveilles, upon which prehistoric man left plenty of engravings, probably thinking a God was living on its highest peak, Mont Bégo at 2,872 m (Bernardini, 1979). 
domains in it, an Alpine one in its higher part and a Mediterranean one in the lower. The vegetation is therefore very varied. ${ }^{3}$

Thanks to this interesting natural landscape, the National Park of Mercantour was created in 1979 to include all of the French Roia Valley, with the exception of La Brigue territory. However, all the Italian part is adjacent to the Regional Natural Park of the Ligurian Alps which was created in 2007. A few years ago, a museum was opened in Tende to host the most fragile engravings of the Vallée des Merveilles, with the main intention being to promote the site, which is quite inaccessible because of its heights.

The settled population in the valley amounts to about 6,000 people, concentrated mainly in Tende and Breil, the only centres with more than 2,000 inhabitants. Tende $(2,157$ inhabitants: datum INSEE, 2013) is situated at $820 \mathrm{~m}$ altitude, and it is a very picturesque historic village with its own castle, local stone roofs, with intriguing mountains surrounding it; while Breil (2,480: datum INSEE, 2013) is located at only $265 \mathrm{~m}$ above sea level, on the bank of the Roia River where it widens and resembles a little lake. The other centres count only some hundreds of inhabitants each. ${ }^{4}$ Like in many isolated mountain places, the population in the Roia Valley developed a unique and original culture, not univocally connectable to any other. The principal evidence of this fact was the local dialect. ${ }^{5}$ In the last few decades, the local community has been affected by globalisation - the presence of immigrants is also quite evident - and today the valley's inhabitants no longer speak their dialect, but tend to speak French, and also English with their guests. In terms of religion, the tradition is certainly Roman Catholic, as can be seen by the presence of many Alpine sanctuaries or chapels welcoming pilgrimages, processions and liturgies primarily during the summer and during folkloric patron saints' festivals, ${ }^{6}$ which can add a certain religious tourist interest.

In terms of the economic activities of the area, the primary and secondary sectors are quite residual. When it comes to farming, sheep and cattle are popular in the valley,

\footnotetext{
${ }^{3}$ Larch trees (Larix decidua) and some endemism like Saxifraga florulenta in the mountains; holm oaks (Quercus ilex), brooms (Ginesteae), olive trees (Olea europaea) and even palm trees (Phoenix dactylifera and Washingtonia) on the coasts, with a very original mix in the transition zone (Martini, 1996).

${ }^{4}$ La Brigue: 719; Airole: 461; Saorge: 442; Fontan: 323; Olivetta San Michele: 225 (data: INSEE, 2013 for France; ISTAT, 2011 for (taly).

${ }^{5}$ The dialect until a few years ago was considered as belonging to the ancient Occitan language, but it is not any more, or even perhaps less linked to it than to Ligurian or Piedmont dialects (Bartaletti, 2009).

${ }^{6}$ Of particular note is the so-called Sistine Chapel of the Maritime Alps in La Brigue, entirely frescoed by Giovanni Canavesio at the end of the $15^{\text {th }}$ century (Pastorelli, 1987).
} 
and both have a direct influence on the traditional food. With regard to industry, the only important enterprises are the seven hydroelectric plants, five of which are in the French territory. ${ }^{7}$ However, the majority of the population of the area works in the tertiary sector, and in part in the tourism sector. As it stands, tourism activities in the area are quite low and have always been more of a transitory tourism nature. The provision for tourists is quite moderate: in 2014 there were only ten hotels registered (one with one star, five with two stars, one with three stars, and three not categorized) with a total of 145 rooms, and three campsites with 119 places (of course, only open during the summer months), one vacation home of six beds, and five B\&B's (data: INSEE, 2014 for France; ISTAT, 2014 for Italy).

About thirty years ago, a ski resort project in Tende (on the opposite slope of the famous resort of Limone in Piedmont) was an attempt, which never came to fruition, to launch the valley on the tourism market (Garibaldi, 2014). ${ }^{8}$ Nowadays, sport lovers can trek or hike in the mountains, go horse riding or canoeing in Breil, or board the via ferrata in Tende and La Brigue, but these are the only tourist attractions of the valley.

\section{The railway line}

The main roadway in the Roia Valley is the European Route E74 (called Strada Statale 20 del Colle di Tenda in Italy and Route Départementale 6204 in France), built during the 16th century and today unsuitable both for commerce and tourism despite several reconstructions since the 1970s.

In 1928 a very important innovation affected Roia Valley communications: the completion of the railway line from Nice/Ventimiglia to Cuneo. Fifty-nine km in length from Ventimiglia to the entrance of the Tende tunnel, the railway line represents a very original engineering feat, with its helicoidal tunnels, steep inclines, and daring viaducts. ${ }^{9}$ The construction of the line encountered a lot of difficulties, due to its international

\footnotetext{
${ }^{7}$ These plants produce about 330 million kWh and provide clean and renewable energy, both to France and Italy (data provided by: Electricité de France, Nice, for France; ENEL S.p.A., Genoa, for Italy).

${ }^{8}$ Today that initiative would be unsuccessful due to the decrease in winter sports and reduction in winter snow in the Southern Alps due to climate change.

${ }^{9}$ From Breil, an alternative $44 \mathrm{~km}$ long line links the valley directly with Nice.
} 
itinerary, the severe geomorphology of the region, the severe climate at altitude, and the limited technology of the time..$^{10}$

Figure 2: The railway bridge of Scarassoui before and after the Second World War
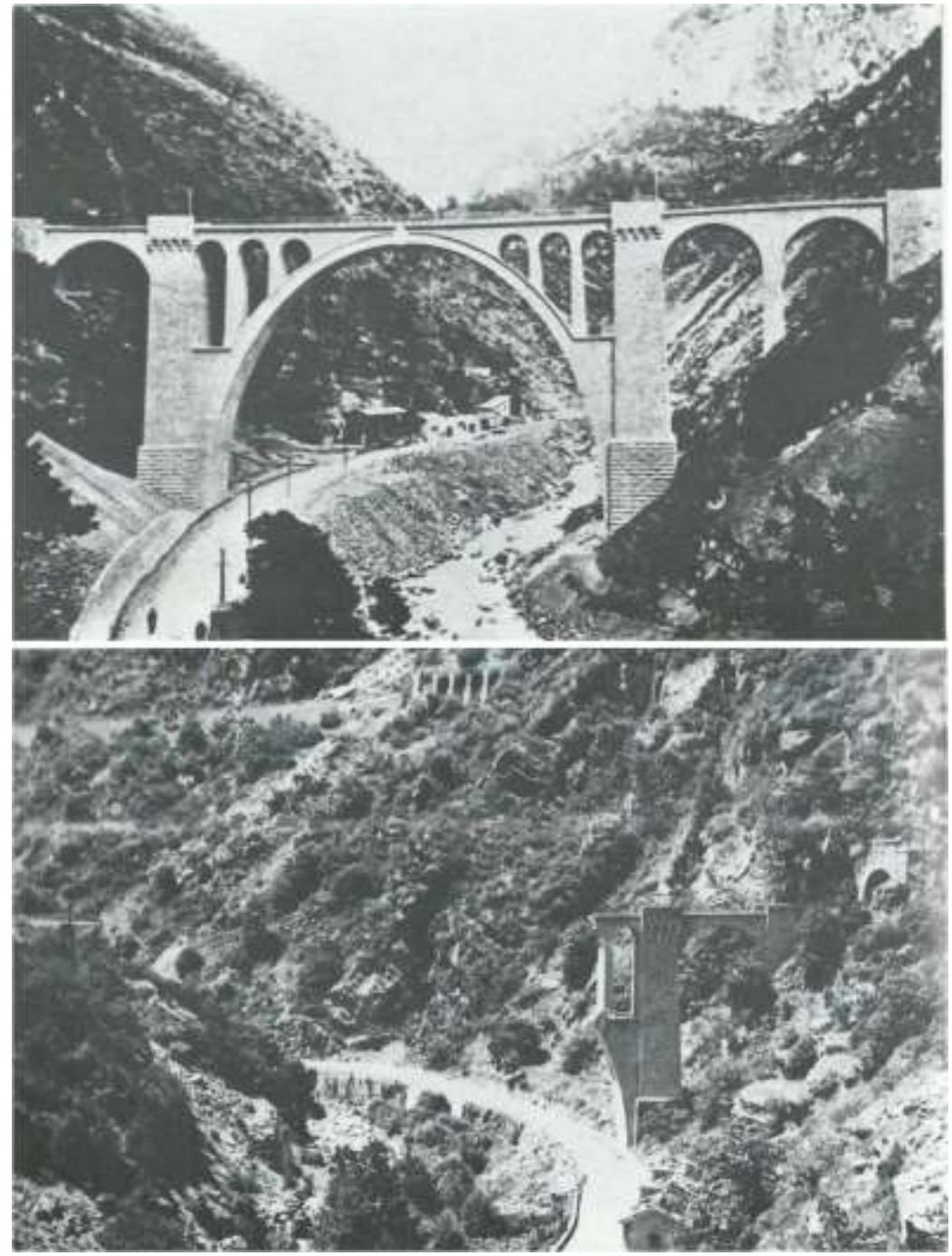

Source: Schiavazzi, 1979.

Unfortunately, on June $10^{\text {th }} 1940$ the war between Italy and France broke out. The Roia Valley railway was eventually a target of extreme war events, and it was literally devastated. In 1945, when peace was restored, the valley presented a very sad landscape with all the bridges destroyed. In the following years the railway line was further damaged by several landslides which worsened the situation. It is possible to say

\footnotetext{
10 Just to give some examples, the railway tunnel under the Tende Pass, 8,099 $\mathrm{m}$ long at an altitude of $1,040 \mathrm{~m}$, required 8 years of work, and the Saorge Bridge, $40 \mathrm{~m}$ long, crossing the river at $50 \mathrm{~m}$ height, required innovative scaffoldings (Schiavazzi, 1979).
} 
that the rebuilding of the Roia Valley railway line was perhaps the last work of the postwar rebuilding: it was only on October $6^{\text {th }} 1979$ that the new line was finally inaugurated after around five years of work.

Figure 3: The Scarassoui bridge under reconstruction and the special postal marking of the inauguration of the new Roia Valley railway line

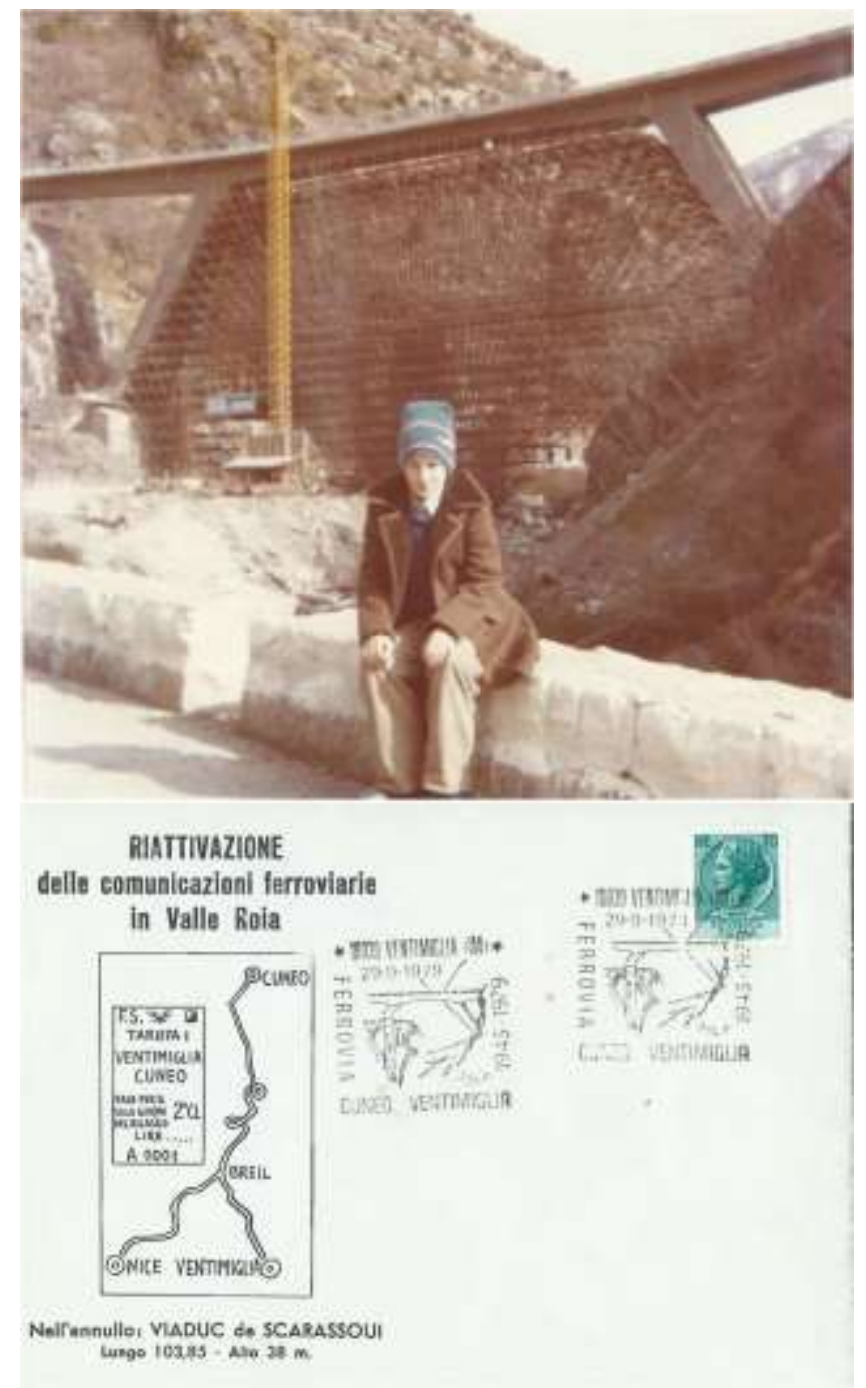

Source: From the author's archive.

In the years that followed, the railway assumed quite a large importance in terms of the connection between the valley's villages, between them and the Ligurian and Piedmontese centres, and between the Riviera and the Alps. ${ }^{11}$ To get to the Tende

\footnotetext{
${ }^{11}$ In relation to the latter, the 'snow train', which for years connected the Riviera towns with the skiing resort of Limone on winter Sunday mornings and late afternoons is worthy of note (established again as an experiment during the 2014-15 winter).
} 
tunnel from Ventimiglia, or vice-versa, the train usually takes 1 hour 40 minutes to cover a distance of only $50 \mathrm{~km}$. This low speed of the trains - due to the sometimes very steep incline of the railway line, but also because they make numerous stops ${ }^{12}-$ is therefore very adequate for the slow tourist approach as it gives tourists the time to savour the journey whilst admiring the interesting landscape from the windows. ${ }^{13}$ Gradually, the railway line's fortune has changed for the worst (nowadays only two trains go in the two directions daily), mainly because of the high costs associated with its maintenance and the low interest demonstrated by the French railway company toward this short line, despite active local public campaigns to safeguard the railway.

Figure 4: French and Italians gathered: train in danger!

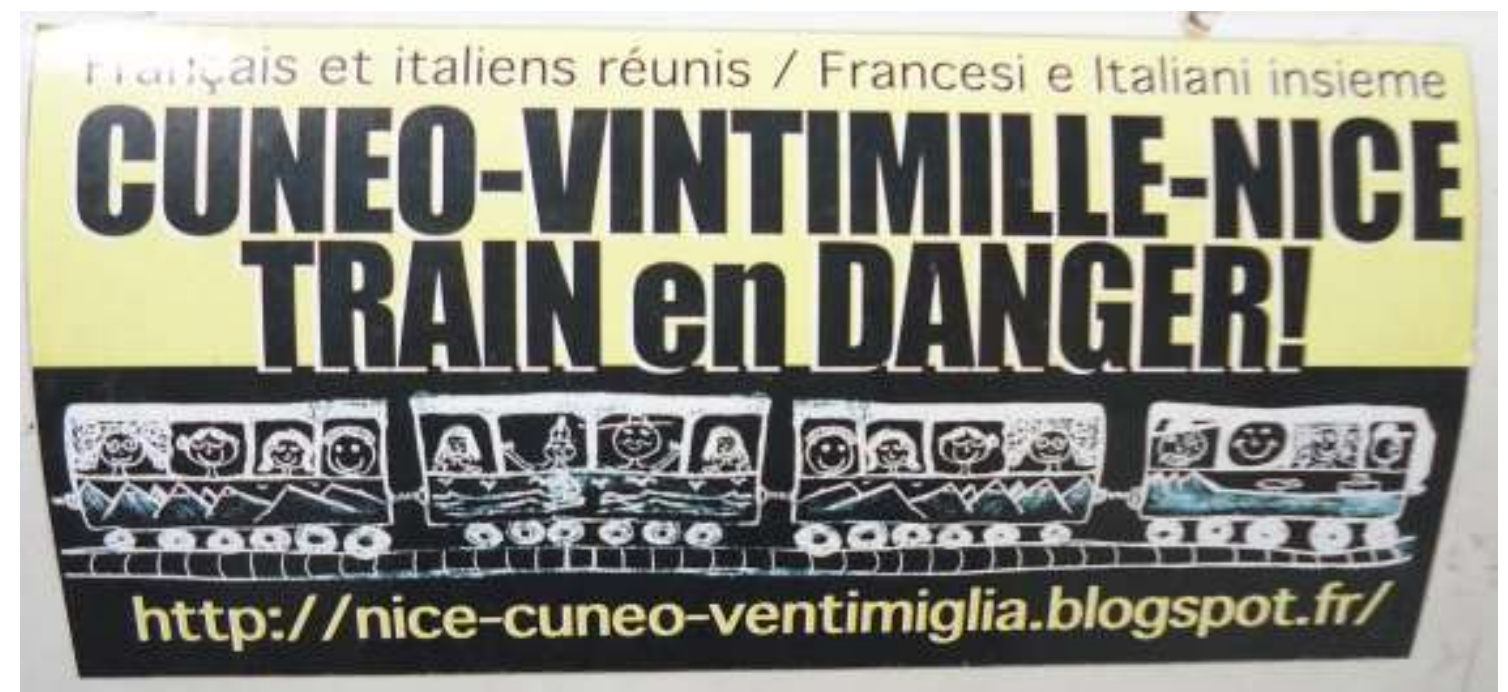

Source: Author's picture.

A clear strong voice from the local community in defence of the line is the geographer Prof. Liliane Pastorelli of La Brigue (University of Nice) - official correspondent of the valley for Nice Matin, the local newspaper of the French Department of Alpes-Maritimes - who fights convincingly to safeguard such a useful means of transport for the inhabitants of the valley.

\footnotetext{
${ }^{12}$ After leaving Ventimiglia, trains usually stop in Bevera (after 6 minutes), Airole (6), Olivetta San Michele (3), Breil (13), Fontan-Saorge (12), Saint-Dalmas-de-Tende (2), La Brigue (7), Tende (8) and Vievola (15), stopping about 1 minute in every station.

${ }^{13}$ The centres of the villages are not always close to the station itself: La Brigue is at about $700 \mathrm{~m}$ away, but the 'Tibetan' village of Saorge - so called because it stretches on the slope of the mountain - is actually at $3 \mathrm{~km}$ from the station serving Fontan and Saorge, and it takes about an hour by foot to cover this distance due to the steep incline linking Saorge with its station.
} 
As it stands, at least until now, forms of railway tourism being proposed in the Roia Valley are very rare, and the majority of tourists going into the valley use private cars, or coaches which are not always suitable for the winding and narrow roads of the region.

\section{The research findings}

To verify interest towards a slow tourism supply in the Roia Valley by potential tourists, the four aspects highlighted by Lumsdon and McGrath (2011) were used.

As previously mentioned, the first aspect highlighted is the full enjoyment of the locality itself. In relation to this aspect, Woehler (2004) affirms that a less regimented approach to holidaymaking is the way in which people can relax, and therefore, enjoy a more sensuous experience with greater emphasis on people and places. Therefore, the primary focus is on the place and its people, to which end we may highlight the pleasantness of the Roia Valley and the activities of its inhabitants, presented above, as potential objects of slow tourist appreciation.

The second aspect within which it is possible to analyse slow tourism is to consider the journey as a core component of the travel experience. The most recommended means of transport for slow tourism are bicycles, trams, trains, buses, or even horses, donkeys, mules... if not the tourist's own feet. In any case, contrary to traditional tourism, "the journey is an integral part of slow travel" (Lumsdon and McGrath, 2011: 268). Therefore, the second stage involved examining the tourist appeal of the communication routes of the Roia Valley, with a particular focus on the railway.

To continue with the aforementioned typology, the third aspect of slow tourism is of course the way in which time is used during the journey. Honoré (2004) clearly states that the idea is to savour time rather than simply count it. In fact, a genuine slow tourist does not only employ alternative slower means of transport, they also have a different attitude towards their time, one which brings them closer to a flâneur (Nuvolati, 2006) than to a traditional mass tourist.

Finally, even if sustainability has been defined as a 'utopia' (or, better, a "necessary utopia" (Manzi, 2001)), it has become necessary to refer to it in every tourist project hoping to be long-lasting in all its environmental, economic, and social dimensions (Saarinen, 2006). To make sustainable tourism a successful choice, it is necessary on the 
one hand for the supply of tourist services to be supported by adequate sustainable policies (and this is the role of the hosts); but, on the other hand, the tourists themselves must prefer and use sustainable tourist services, both to maximize their own leisure experience and to minimize their negative impact on the territory (and this is the role of the guests). It can be argued that sustainability is only possible if the local community and the tourists together have what Lumsdon and McGrath (2011: 69) call an environmental, social and economic "discernible green consciousness".

It is therefore possible to draw up Table 1 in which the different aspects of the region have been put in relation to the interest they created among the participants of the research according to the four above-mentioned criteria.

Table 1: Interests of potential slow tourists towards the Roia Valley

\begin{tabular}{|l|c|c|c|c|}
\hline & $\begin{array}{c}\text { APPRECIATE } \\
\text { THE PLACE }\end{array}$ & $\begin{array}{c}\text { ENJOY THE } \\
\text { JOURNEY }\end{array}$ & $\begin{array}{c}\text { SAVOUR } \\
\text { TIME }\end{array}$ & $\begin{array}{c}\text { CONCERN WITH } \\
\text { SUSTAINABILITY }\end{array}$ \\
\hline \multicolumn{5}{|c|}{ ENVIRONMENT } \\
\hline GEOMORPHOLOGY & + & $\mathrm{n} / \mathrm{a}$ & +++ & +++ \\
\hline CLIMATE AND VEGETATION & ++ & $\mathrm{n} / \mathrm{a}$ & $\mathrm{n} / \mathrm{a}$ & +++ \\
\hline ENGRAVINGS & + & $\mathrm{n} / \mathrm{a}$ & + & +++ \\
\hline NATURAL PARKS & + & $\mathrm{n} / \mathrm{a}$ & + & +++ \\
\hline MUSEUM OF MERVEILLES & ++ & $\mathrm{n} / \mathrm{a}$ & ++ & + \\
\hline \multicolumn{5}{|c|}{ CULTURE } \\
\hline HISTORICAL VILLAGES & +++ & $\mathrm{n} / \mathrm{a}$ & ++ & + \\
\hline DIALECT & ++ & $\mathrm{n} / \mathrm{a}$ & + & $\mathrm{n} / \mathrm{a}$ \\
\hline RELIGION & + & $\mathrm{n} / \mathrm{a}$ & + & $\mathrm{n} / \mathrm{a}$ \\
\hline ART & + & $\mathrm{n} / \mathrm{a}$ & + & + \\
\hline \multicolumn{7}{|c|}{ ECONOMY } \\
\hline BREEDING & + & $\mathrm{n} / \mathrm{a}$ & $\mathrm{n} / \mathrm{a}$ & + \\
\hline FOOD & ++ & $\mathrm{n} / \mathrm{a}$ & ++ & ++ \\
\hline RENEWABLE ENERGY & ++ & $\mathrm{n} / \mathrm{a}$ & + & +++ \\
\hline LEISURE AND SPORT & + & $\mathrm{n} / \mathrm{a}$ & + & + \\
\hline \multicolumn{7}{|c|}{ POLITICS } \\
\hline BORDERS & ++ & $\mathrm{n} / \mathrm{a}$ & ++ & $\mathrm{n} / \mathrm{a}$ \\
\hline PLACE-NAMES & +++ & $\mathrm{n} / \mathrm{a}$ & $\mathrm{n} / \mathrm{a}$ & $\mathrm{n} / \mathrm{a}$ \\
\hline & ++ & + & + & + \\
\hline ROAD & ++ & +++ & +++ & $\mathrm{n} / \mathrm{a}$ \\
\hline RAILWAY (VIEW) & +++ & +++ & +++ & ++ \\
\hline RAILWAY (ENGINEERING) & ++ & +++ & +++ & +++ \\
\hline RAILWAY (HISTORY) & +++ & +++ & ++ \\
\hline RAILWAY (IDENTITY) & ++ & + \\
\hline TRANSORTS & + \\
\hline
\end{tabular}

Key: + low; ++ medium; +++ high; n/a not applicable.

Source: Data from the research. 
All the aspects created - when applicable - a relatively high level of interest in the participants of the survey. It is thus possible to conclude that the suitability of a slow tourism supply in the valley seems to be confirmed. ${ }^{14}$

However, it is useful to focus more on the train, which received the highest level of interest in almost all its aspects. According to the tourists, the railway would be very suitable for enjoying the valley, because of its scenic views and the possibility to appreciate it more and discover its intrepid engineering. Also, the history of the railway line - intricately linked with the war, the displacement of the boundaries, and the 'Frenchification' of the place names - as well as the strong identity links between the inhabitants of the valley and the railway line, were the most appreciated themes of the day. Therefore, using the train seems compatible with the major interests of the potential slow tourists.

During the informal conversations, interest in using the train for a slow tourism experience instead of the coach was clearly expressed, and some observations were made. For instance, some participants openly criticized choosing to use a tourist bus because it was unsuitable for getting to know all the aspects of the valley, and some others highlighted the sustainability of rail transport contrary to road transport; someone was interested in knowing the exact travel times of the trains, and another one suggested the need to envisage up-to-date devices such as smart technologies on the trains as a way of encouraging tourists to use the train; finally there was who complained of suffering from travel sickness when travelling by coach on the winding road!

Finally, there is an important aspect that emerged during the fieldwork, and this is that it is not quite the right time to expand the tourist provision in Roia Valley, with a view to ensuring sustainability. As a solution, there is an interesting suggestion that could be put in place without too much effort, with a good perspective on local development, and suitable for launching slow tourism: this is 'alberghi diffusi'. An 'albergo diffuso' (literally: dispersed hotel) is a type of accommodation unit, conceived in Italy in the 1980s, which has also been successful in Croatia, Switzerland and France.

\footnotetext{
${ }^{14}$ It is pertinent to remember here that the six dimensions that slow tourism has to simultaneously satisfy according to the authors of the Italian-Slovenian "Strategic project of cross-border cooperation 20072013" (Zago, 2012) - time, slowness, authenticity, dialogue, emotion, and sustainability - seem here to be present, too.
} 
It is usually situated in a historic centre, or in a special area characterized by a lively community, located in many converted buildings each close to one another, with a unitary management able to provide normal hotel services from a central reception. Therefore, the 'albergo diffuso' is able to create a strong link with the territory, to supply a genuine local atmosphere to the tourists and, in the meantime, integrate the minor villages and rural areas needing an economic relaunch on the tourist market (Droli and Dall'Ara, 2012). This interesting tool seems suitable for a slow tourism proposal, because it can bring together the needs of the local community and the new tourists' tastes, in a positive and long-lasting way. Moreover, as Costa (2005) clearly says, if with low tourist flows (like in the Roia Valley) the regulation of accommodation and leisure activities is quite high, when the flows increase, it would be easier to manage the territory in a sustainable way.

\section{Conclusion}

As has been shown, creating a slow tourism programme in a territory means, in brief, to propose to visitors:

[A] value which leads to a reconfiguration of the time and quality of experience, an integral element of journey, and the modal choice of transport that offers a richer experience. Slowness also sheds some light on consumer behaviour and, in particular, highlights that environmental consciousness is an important element of a slow travel approach (Lumsdon and McGrath, 2011: 269).

Of course the hosts are also affected by such an innovation, and so many aspects are deserving of an appropriate debate within the local community. Every action grows from mediation and negotiation, and to do this it is necessary to have a genuine and trustworthy social climate: to achieve a result it is necessary to have the positive and optimistic attitude that agreements are possible if everyone is willing to put a limit to their own claims.

In the past the Roia Valley has too often been subject to decisions that did not come from below, that were not shared, or long-lasting, or promising. However, its population still believes in a better future for the region. The railway line seems to truly symbolize the valley: with its arduous route, the terrible destruction followed by its perfect 
restoration, its slow, but conclusive progress. It has rightly assumed a strong link and meaning for the identity of the inhabitants. To use it as a means for tourists to discover the valley could mean sharing the local identity, but this must be done in a delicate manner, in a way slow tourism knows best.

\section{References}

Bagnoli, L. (2006). Beni culturali e conflitti armati. In G. Cusimano (Ed.), Luoghi e turismo culturale (pp. 61-80). Bologna: Pàtron.

Bagnoli, L. (2013). Italian far west - Rediscovering boundaries and memories. In M. Calloni and E. H. Botting (Eds.), Border, sovereignty, rights. The border crossing seminar BCS 1 (pp. 7379). Milan: University of Milano-Bicocca.

Bartaletti, F. (2009). Geografia e nomi di luogo nelle region di confine: Gli esempi del Sudtirolo, dell'Istria e dell'ex-provincia di Nizza. Genoa: Bozzi.

Bernardini, E. (1979). Le Alpi marittime e le meraviglie del Monte Bego. Genoa: Sagep.

Blancheton, B. \& Marchi, J.-J. (2011). Le développement du tourisme ferroviaire en France depuis 1870. Histoire, Economie \& Société, 30 (3), 95-113. doi : 10.3917/hes.113.0095

Calzati, V. \& De Salvo, P. (Eds.) (2012). Le strategie per una valorizzazione sostenibile del territorio: Il valore della lentezza, della qualità e dell'identità per il turismo del futuro. Milano: FrancoAngeli.

Costa, N. (2005). I professionisti dello sviluppo turistico locale. Milano: Hoepli.

Droli, M. \& Dall'Ara, G. (2012). Ripartire dalla bellezza. Gestione e marketing delle opportunità d'innovazione nell'albergo diffuso nei centri storici e nelle aree rurali. Padua: Cleup.

Florida, R.L. (2002). The Rise of the Creative Class: And how it's transforming work, leisure, community and everyday life. New York: Basic Books.

Franch, M., Sambri, C., Martini, U., Pegan, G. \& Rizzi, G. (2008). La domanda di turismo responsabile e di eco-turismo in Italia. Un'indagine esplorativa sui turisti CTS. Paper for the Marketing Trends International Meeting (21 p.). Venice: Università Ca' Foscari.

Garibaldi, G. (2014). Tra Centa e Roia: Uno sguardo geografico: Ambiente, popolazione, economia dei comuni riviereschi e interni dell'estremo Ponente ligure. Sanremo: Imperia: Associazione italiana insegnanti di geografia.

Georgica, G. (2015). The tourist's perception about slow travel - A Romanian perspective. Procedia Economics and Finance, 23, 1596-1601. doi: 10.1016/S2212-5671(15)00557-2

Honoré, C. (2004). In praise of slowness: How a worldwide movement is challenging the cult of speed. San Francisco: Harper.

House, J.W. (1959). The Franco-Italian boundary in the Alpes Maritimes. Transactions and Papers (Institute of British Geographers), 26, 107-131. doi: 10.2307/621046

Institut National de la Statistique et des Études Économiques $(2013,2014)$. [Bases de données]. Available at www.insee.fr

Istituto Nazionale di Statistica $(2011,2014)$. [Banche dati]. Available at www.istat.it

Knoblauch, H. (2005). Focused ethnography. Forum: Qualitative Social Research, 6 (3).

Loda, M. (Ed.) (2010). La ricerca empirica nel lavoro del geografo. Geotema, 41, 96-104.

Lucarno, G. (1992). Sulla gestione delle linee ferroviarie di confine. Aspetti politici ed economici. Studi e ricerche di geografia, 2, 133-174.

Lumsdon, L.M. \& McGrath, P. (2011). Developing a conceptual framework for slow travel: A grounded theory approach. Journal of Sustainable Tourism, 19 (3), 265-279. doi: 10.1080/09669582.2010.519438 
Manzi, E. (2001). Paesaggio, turismo e sostenibilità ambientale. Qualche indicazione per una utopia necessaria. Bollettino della Società Geografica Italiana, XII (6), 389-403.

Martini, E. (1996). Fiori protetti in Liguria. Genoa: Regione Liguria.

Nuvolati, G. (2006). Lo sguardo vagabondo. Il flâneur e la città da Baudelaire ai postmoderni. Bologna: II Mulino.

Pastorelli, L. (1987). La brigue au coeur. Nice [Published by author].

Ruocco, D. (1993). Riflessioni geografiche. Napoli: Geocart Edit.

Saarinen, J. (2006). Traditions of sustainability in tourism studies. Annals of Tourism Research, 33 (4), 1121-1140. doi: 10.1016/j.annals.2006.06.007

Schiavazzi, G. (1979). Ferrovia Cuneo-Ventimiglia: Una storia di prodezze tecniche, battaglie politiche, fatti di guerra, tenacia. Ventimiglia: Comitato Intermelio per la CuneoVentimiglia.

Shaw, G. \& Williams, A.M. (1994). Critical issues on tourism: A geographical perspective. Oxford: Blackwell.

Woehler, K. (2004). The rediscovery of slowness, or leisure time as one's own and as selfaggrandizement? In K. Weiermair \& C. Mathies (Eds.), The tourism and leisure industry: Shaping the future (pp. 83-92). New York: Haworth.

Zago, M. (2012). Definire e operativizzare lo slow tourism: II modello Castle. In V. Calzati \& P. de Salvo (Eds.), Le strategie per una valorizzazione sostenibile del territorio: Il valore della lentezza, della qualità e dell'identità per il turismo del futuro (pp. 155-170). Milano: FrancoAngeli.

LoRenzo BAgnol (M.Sc. in Political Science; M.Sc. in Geography; M.A. in International Cooperation Development; Ph.D. in Geographic, Environmental and Cartographic Science) is an associate professor in Geography at the University of Milan-Bicocca, Italy. He teaches Geography of Tourism on the graduate course in 'Science of tourism and local community' and Cartography for Tourism on the masters course in 'Tourism, territory and local development'. In the latter, he is the vice-president and he is also responsible for international relations. He is vice-president for pedagogical concerns of the International Tourism Master Network (ITMN). His main research interests are the geography of tourism, cartography and the geography of heritage, with particular focus on their historical, political and social aspects. Institutional address: Università di Milano-Bicocca; Dipartimento di Sociologia e Ricerca Sociale, Via Bicocca degli Arcimboldi, 8, 20126 Milano, Italia.

Submitted: 16 November 2015.

Accepted: 09 March 2016. 